\title{
Characteristics of Roads Approaching Flood Protection Dikes, Factors Affecting Their Use, Main Problems and Challenges of Their Reconstruction
}

\author{
Az árvízvédelmi töltéseket megközelítő utak jellemzői, \\ használatukat befolyásoló tényezők, helyreállításuk \\ problémái és feladatai
}

In recent decades, a significant number of extreme-level flood waves have occurred in Hungary. In order to prevent and reduce flood damage, several intervention works have been carried out by organisations involved in flood protection. During these works the protective materials (sand, sacks, planks, stakes, and so on), human labor, heavy machinery and other equipment were transported along the flood protection dikes many times. These approaching routes have different pavements, bearing capacity and ownership, which make their use difficult. In this article, the author presents the typical features of these routes, the characteristics of their usage and its technical consequences, and also the reconstruction tasks needed following the flood protection works. The author made cost and price analysis for the reconstruction of different types of approaching routes and dike crown roads based on data collected from the operation area of the Middle-Tisza District Water Directorate (KÖTIVIZIG).

Keywords: flood protection, damage control, reconstruction, approach route

Hazánkban az elmúlt évtizedekben jelentős számban fordultak elő a nagy vizhozamú folyóinkon levonuló rendkivüli árhullámok. Az árvizek károkozásának megelőzése és csökkentése érdekében különböző beavatkozási munkák történtek a védekezésben részt vevő szervezetek részéröl. Ezek végrehajtása során, számos esetben az árvízvédelmi töltések mentén folytak a szállitási feladatok

Middle-Tisza District Water Directorate, technical deputy director, e-mail: horvath.lajos@kotivizig.hu, ORCID: https://orcid.org/0000-0003-1499-503X 
(a védekezéshez szükséges eszközök, anyagok és személyek), valamint a nehéz munkagépek kárhelyre történő bejuttatása. Az ilyen megközelitő utak különböző burkolatúak, teherbírásúak és eltérö tulajdoni viszonyúak, amelyek sok problémát okoznak az igénybevételük során. Ebben a cikkben a szerző bemutatja az árvízvédekezések alkalmával ideiglenesen használt utak müszaki jellemzőit, az igénybevétel formáit, müszaki következményeit, valamint a kárelhárítási beavatkozásokat követően az utak helyreállításának feladatait. A szerző a Közép-Tisza-vidéki Vízügyi lgazgatóság (KÖTIVIZIG) müködési területének jellemzői alapján költség- és árelemzést végzett a különböző útburkolatú bekötö- és töltéskoronai utak rekonstrukciós munkáira vonatkozóan.

Kulcsszavak: árvízvédelem, kárelhárítás, helyreállitás, megközelítő útvonal

\section{Introduction}

After the 1990s there were several flood waves on River Tisza and its tributaries which entailed an extreme-level flood alert, ${ }^{2}$ th is way causing significant additional load on the flood protection infrastructure. These floods required serious financial resources, machinery and human labor during the protection and reconstruction works from the water management sector and the associatied organisations. Besides the water directorates responsible for flood protection works, it was necessary to involve external organisations which could supply the needed machinery and technical equipment (for instance civil protection, military, construction companies, entrepreneurs, service companies, and so on).

KÖTIVIZIG (Middle-Tisza District Water Directorate) is responsible for flood protection works on a total of $707 \mathrm{~km}$ of primary-level flood protection line in case of an extreme level alert. $^{3}$ This flood protection infrastructure consists of mostly unpaved earth dikes. Flood protection dikes are by nature trace-type structures following riverbanks and are located mainly in the periphery. In rainless weather there is easy access to them even by 3.5 tons trucks, however, approaching them by trucks exceeding 3.5 tons total weight or in rainy weather is difficult.

There is a chance for flood waves in the future on River Tisza which are larger than those in the past decades, ${ }^{4}$ therefore we have to be prepared to fight these floods and for the interventions needed to grant civil safety.

The actuality of the discussed topic is also proven by the fact that with the rising level of future flood waves and failed developments we can expect serious flood protection works in the future, which will require significant transporting capacity. In case of future floods the availability of the material needed and human resources should be provided according to the

10/1997. (VII. 17.) KHVM rendelet az árvíz- és a belvízvédekezésről [KHVM regulation about flood and excess water protection], 12-16. §.

3 10/1997. (VII. 17.) KHVM rendelet az árvíz- és a belvízvédekezésről [KHVM regulation about flood and excess water protection], Annex 1, 579-622. rows.

4 Sándor Kovács, Attila Lovas and Károly Gombás, 'Magyarország árvízvédelme az integrált vízgazdálkodásban a Tisza folyó példáján' [Flood protection of Hungary in integrated water management demonstrated on the example of River Tisza], Hidrológiai Közlöny, no 4 (2016), 6-19. 
' $5 \mathrm{M}^{\text {' compliance rule }}$ of logistics (the right quantity, in the right time, in the right quality, in the right place with the right costs). At the moment the preparation plans of the water management sector contain only the material and human resource needs of the protection works for each alert level. However, an organising plan for transportation would also be needed, because approaching flood protection facilities is a special task, so the relating plans should already be available in the preparation phase.

Publications about flood protection works are common in Hungarian literature, but they don't examine either the availability of service roads needed for protection works nor the strain of their utilisation or the way and financing of their reconstruction. I found only one example for a publication directly examining the transportation (aerial, inland, maritime) of flood protection material and the construction of flood protection roads. ${ }^{6}$

My aim is to demonstrate the types and ownership of flood protection roads used during the flood protection works in the operation area of KÖTIVIZIG, and to make a cost analysis relating to the reconstruction of these roads.

I feel it important to draw the attention of experts to the importance of the damage and reconstruction of transportation roads during the preparation for flood protection works along primary protection lines. The organising of transportation of protection material should be done in a methodical and scheduled way, taking the available financial resources into consideration.

\section{Flood protection organisational structure of KÖTIVIZIG}

The basic tasks of the water management sector - thus including KÖTIVIZIG as well - are recorded mainly by the deed of foundation ${ }^{7}$ and also Act LVII. of 1995 on Water Management, ${ }^{8}$ 232/1996. (XII. 26.) Government regulation ${ }^{9}$ and 7/2012. (II. 10.) instruction of the Minister of Interior. ${ }^{10}$ The tasks of the water directorate within its territory are given by the state of Hungary and they include the water management of surface and ground waters such as: flood protection, river regulation, excess water management, drainage, agricultural water supply, water quality protection, environmental damage control and the operation of water management facilities.

According to the specifications of the Act on Water Management, the tasks of water related protection works - construction, development, maintenance and operation of protective structures, flood protection works - are the responsibility of the state, the local municipalities

5 Rudolf Tóth and Júlia Hornyacsek, 'Gondolatok a katasztrófa-elhárítás logisztikai kérdéseiröl' [Thoughts about the logistics of disaster prevention], Polgári Védelemi Szemle különkiadás (2008), 93.

6 László Nagy, Árvízvédekezés a településeken [Urban flood protection] (Budapest: Környezetvédelmi és Vízügyi Minisztérium, 2009), 210-222.

7 KÖTIVIZIG Alapító Okirat [Deed of Foundation] (Budapest, 2019), 4.3.

8 1995. évi LVII. törvény a vízgazdálkodásról [Act on Water Management]. Available: https://net.jogtar.hu/jogszabaly?docid=99500057.tv (19. 04. 2020.)

9 232/1996. (XII. 26.) Korm. rendelet a vizek kártételei elleni védekezés szabályairól [Gov. regulation about the rules of protection works against water damages].

10 7/2012. (II. 10.) BM Utasítás a vízkárelhárítás országos irányításának szervezeti és működési szabályzatáról [BM instruction on the rules of organisation and operation relating to protection works against water damages]. 
and all those who are concerned in the prevention or protection against damages. As a result of other provisions of this law, certain tasks to be performed by those who are obliged can be identified based on the ownership of the protective structures.

KÖTIVIZIG is a middle-size directorate with a territory of $7,179.5 \mathrm{~km}^{2}$ comprising 109 settlements, however, considering the magnitude of both its water damage control system and the protected area, it is one of the largest. $23 \%$ of Hungary's territory $\left(21,200 \mathrm{~km}^{2}\right)$ is threatened by floods, and $19 \%$ of those areas $\left(4,057 \mathrm{~km}^{2}\right)$ is located within the territory of KÖTIVIZIG. The area of Jász-Nagykun-Szolnok County is $5,607 \mathrm{~km}^{2}$ and $4,245.5 \mathrm{~km}^{2}$ of that is threatened by floods, which means $76 \%$ of the county.

These data show that in terms of excess water and flood risk the Middle-Tisza District and Jász-Nagykun-Szolnok County has one of the most unfavourable hydro- and geography in the country.

Relating to the potential damages, like those occurring during a flood, our directorate is managing the technical operations, while actions relating to civilians (evacuation, rescuing, social and healthcare, and so on) are made by local municipalities, authorities (for example, National Public Health and Medical Offer Service) and the civil protection through the management of protection committees.

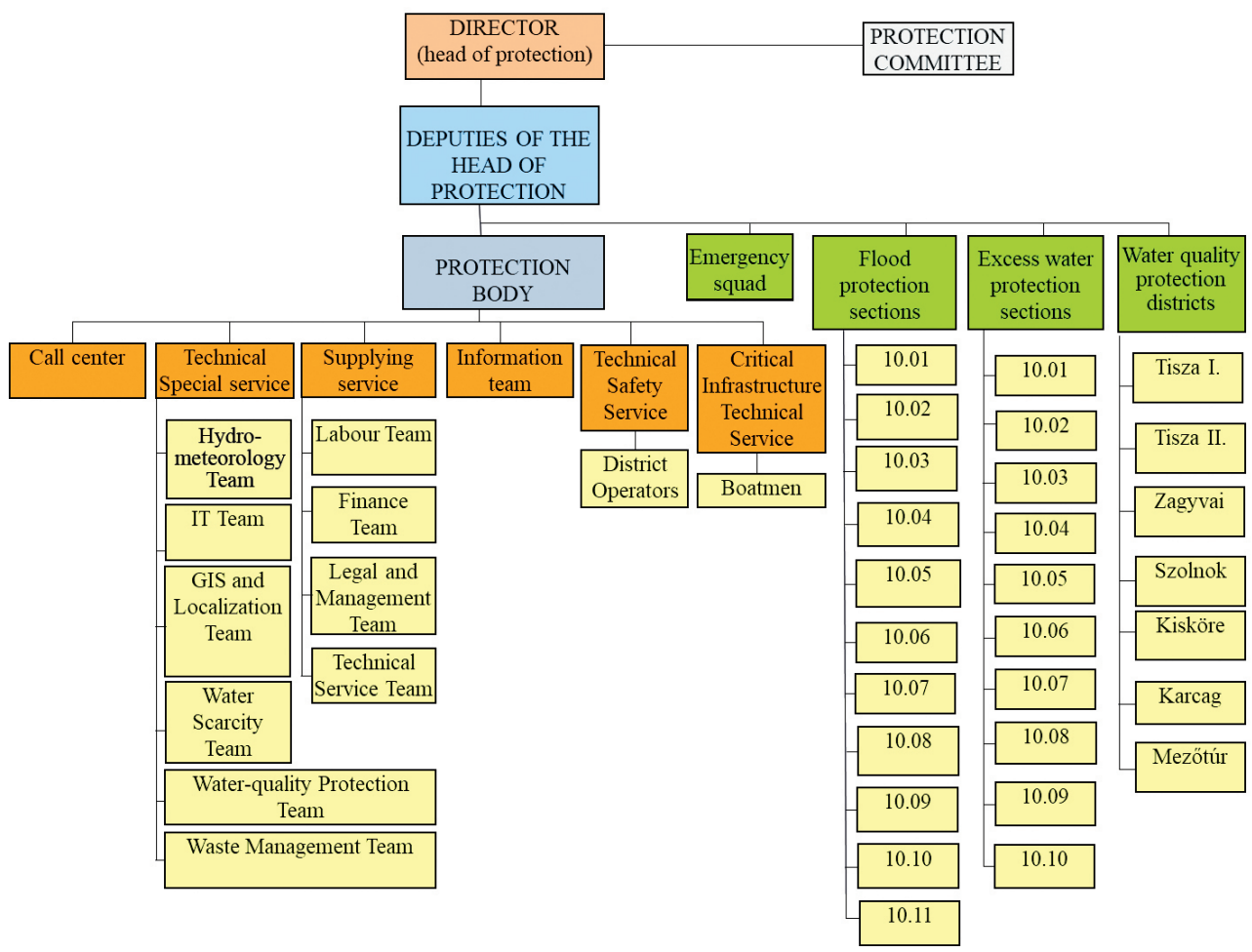

Figure 1. Protection organisation structure of KÖTIVIZIG

Source: edited by the author 
Because of the length, age and state of the special protection facilities like earth dikes, it is very important to maintain a constant dike guard service and also an assisting watch service for the time of protection works. The guard system is one of the most important elements of the protection organisation during flood protection works, and the basic unit of that is the patrolled section. The general organisational structure of the water directorate is very unique, as it operates in two basic 'operation status': normal (peacetime) state, which means the period out of protection alert, and protection alert.

The present organisation structure of the directorate - as it was proven by past flood waves, including the 'Flood of the Century' - is capable of the technical management of flood protection. However, even smaller flood waves require the involvement of the local municipalities, the civilians and contracted entrepreneurs, and the contribution of the Protection Committee. Sometimes, in extreme-level alert, even the help of the army is needed.

\section{Factors hindering approach to flood protection dikes. Transportation types}

Technical interventions during flood protection works require significant machine power. This includes the mobilisation and transportation of protection material, but also earthwork may be needed. Heavy trucks are involved to the greatest extent. Given their location, the approach of flood protection dikes is a special task. As there is not always access to them from paved public roads, the trucks used for transportation should meet special requirements.

During the planning of flood protection works, the type of pavement and the quality of the roads to be used should be taken into consideration. In many cases the material should be moved on unpaved dike crowns or dirt roads, which require special ability trucks in rainy weather. Protection works are done parallel to the flood wave and there is no time to wait until the road conditions improve for normal trucks. In certain cases suitable machinery (bulldozer, scraper, grader, and so on) is needed for the continuous maintenance of the approach routes in order to provide the right conditions for flawless transportation.

The bearing capacity of the approach route is also critical, as it is not always possible to perform optimal transportation with the vehicles of the water directorate and its contracted partners in case of emergency. Traffic on the dike crowns in rainy weather is limited. During transportation we must not cause additional damages which could reduce the protective capacity of the flood protection facility. Where we cannot use higher loading capacity trucks without off-road abilities, a compromise is needed. This means that during the planning of intervention, in order to provide the needed protection material in the right time and right cycle, a larger number of off-road vehicles with lower loading capacity should be used. In most of the cases, pickup trucks are used, which are able to transport 1 ton of protection material safely. In case the conditions of the transport line do not make it possible to use the total loading capacity of the vehicles, we need to lower the transported volume. We cannot allow to slow down transportation as a result of improper load, to reduce safety or to block the transportation line by a vehicle stuck in the mud. While planning the transportation lines we should take into 
consideration and should inform the drivers that transport on flood protection dikes is not the same as on public roads. The road is narrow, sometimes only 3 meters, the surface is unpaved, with one-way traffic and steep slope on both sides, and the water of the flooded river makes it even more dangerous. It happened several times that when the driver faced the conditions declined to participate, which is a risk the person in charge should calculate with.

If the location of certain protection works does not have any road access or can be approached only with a serious detour, a new transport road should be marked out or a flood protection road should be built. An example is the road near Tiszasüly in the year 2000 (Figure 2).
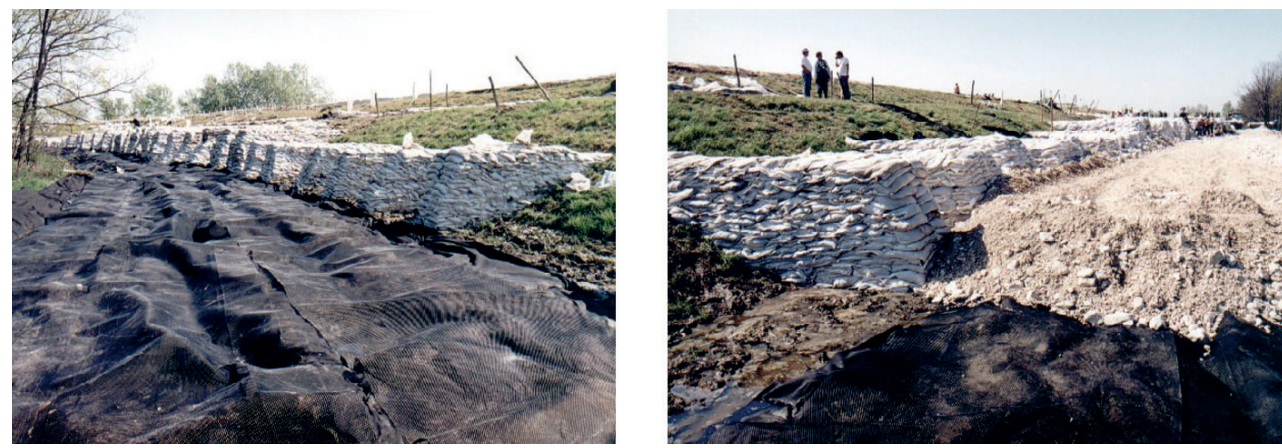

Figure 2. Construction of flood protection road of gravel at Tiszasüly in 2000.

Source: KÖTIVIZIG, inner network (intranet), 2000

Flood protection roads can be built of gravel, logs (Figure 3) or concrete sheets. When selecting the road material we should consider the shortest distance and the easiest availability in time.
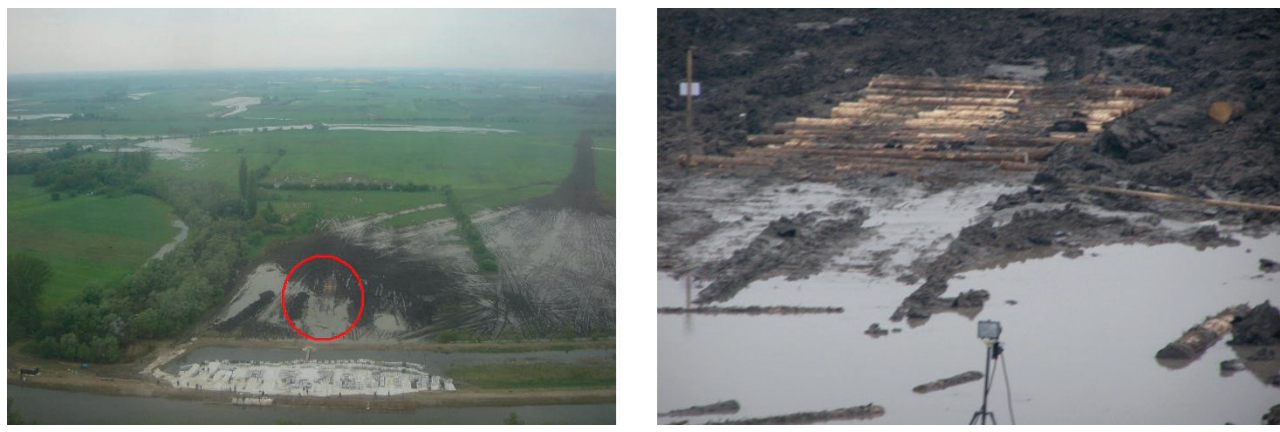

Figure 3. Flood protection road made of logs in an agricultural area near Csongrád in 2006.

Source: KÖTIVIZIG, inner network (intranet), 2006

These temporary roads can cross agricultural, industrial, urban, periphery and any other type of areas, so the vehicles and machinery for the transportation of the road material should be selected carefully. The top priority is to finish transportation as soon as possible, this way enabling the start and continuous progress of further constructions. In every case the chain of 
machinery should be selected and planned in a way to match this transportation line and the number of machines should be calculated in accordance with the material volume required by the given task. If the transportation road is not located on the dike crown, agricultural tractors with trailers can also be involved. When immediate intervention is necessary, the loading and unloading times need to be taken into account, which can be accelerated by using suitable machines instead of human labor and by using tip trucks for easier unloading.

Of course, this works only in certain cases, like with prefilled sandbags or granulous materials, while wooden planks will still need human labor. In case of unfavourable road conditions, when it is impossible to use the above mentioned machines - but also parallel to those - special military machinery can also be involved. Amphibious transportation tracks are universal to use in these cases (Figure 4).
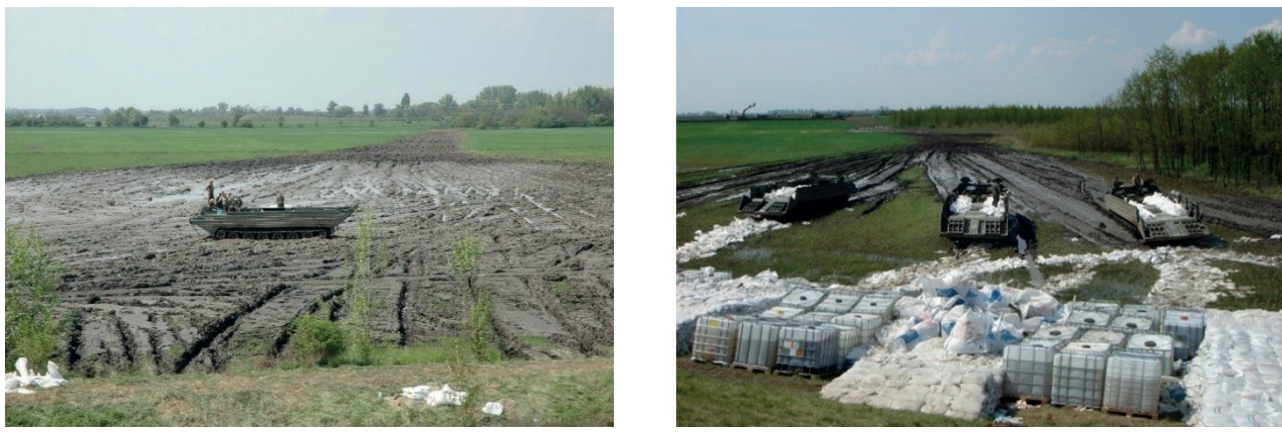

Figure 4. Inland transportation of protection material near Csongrád and Kunszentmárton in 2006.

Source: KÖTIVIZIG, inner network (intranet), 2006

The other reason why transporting vehicles with different functions are also needed is the diversity of the protection materials. For example it is impossible to transport six meters long wooden planks by short platform trucks, consequently the transportation capacity should be chosen depending on the material to be transported.

Inland transportation is not always the fastest solution, so aerial and maritime transportation should also be taken into consideration for flood protection works.
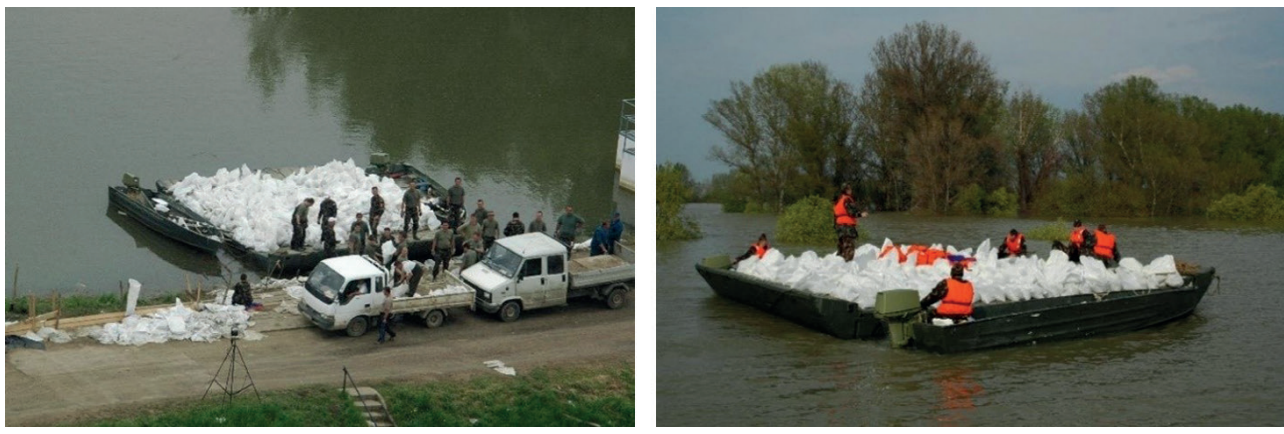

Figure 5. Maritime transportation of protection material near Csongrád in 2006.

Source: KÖTIVIZIG, inner network (intranet), 2006 
In case of maritime transportation the flood protection lines are accessed from the riverside (Figure 5). The vegetation of the floodplains can seriously affect the accessibility, which should be taken into consideration during the planning phase, and it might be investigated if the registered cuts for the ships are available and are in good condition. The availability of maritime transport equipment is limited, they can be found mainly in the fleet of the water directorates, the army and at private companies. It is important to locate carefully the loading areas, to where the protection materials also need to be transported.
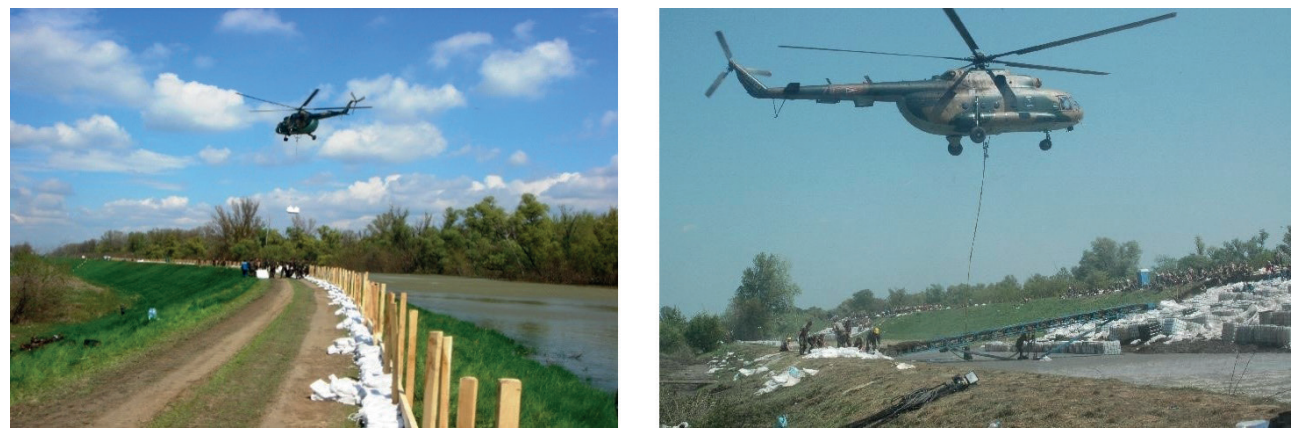

Figure 6. Aerial transportation of protection material near Csongrád in 2006.

Source: KÖTIVIZIG, inner network (intranet), 2006

Aerial transportation of protection material is a very special task, as it is regulated by strict flight control rules, and it can be managed only by other organisations than water directorates (Figure 6). The close cooperation and continuous communication between the army and the water management sector is of vital importance. The primary aircrafts used for aerial transportation are helicopters, which are capable of lifting and moving serious weight up to 1-2 tons. This transportation method is mainly used in case of rapid interventions, as the ready-made materials can be transported to the desired location almost immediately. The protection material (mainly big-bags filled with prefilled sandbags) is hung from the helicopter on a wire cable and is put down exactly on the previously marked spot. Unloading causes severe turbulence in the working area, which requires increased attention from everyone on site, and it should also be prevented that equipment or material (for example empty sandbag) is taken up by the turbulence. The only disadvantage is that powerlines and trees can limit the movement of the aircraft and the possible unloading places. The planning, organising and managing of the transportation of protection material, equipment and personnel is an essential and very complex logistical task.

\section{Types of approach routes used during protection works}

The roads used for approaching protection work locations can be differentiated as constantly used, already existing public roads (occasionally private roads) or temporary roads constructed for the flood protection works. 
Based on ownership they can be categorised as state-owned public roads, local municipality roads and private roads open or closed to public traffic. Roads on water directorate operated flood protection dikes spoil banks of irrigation, and excess water channels in areas operated by other water directorates are open to public traffic for vehicles under $3.5 \mathrm{t}$ total weight assuming the relating licence is paid. Vehicles exceeding $3.5 \mathrm{t}$ total weight are generally not allowed to use the roads operated by the water directorates. The exceptions are the vehicles with individual case-by-case licence, machinery participating in the maintenance work of the facilities and, of course, the vehicles involved in flood protection works.

Approach routes can also be distinguished by their pavement. Typically they are unpaved dike crowns and dirt roads in the periphery, however, there can be sections with solid pavement. These are paved mainly by gravel, tarmac, concrete or paving-blocks.

Gravel roads are typical for low-traffic and occasional use. At the water directorate, gravel roads are built to get access to excess water pump stations and other remote buildings, as occasionally these need to be inspected and maintained even in peacetime. In case of flood alert these roads also serve as transportation lines for fuel (diesel pump stations) and personnel.

The directorate uses tarmac pavement on road sections with higher, constant traffic, where there is daily transport needed for fulfilling everyday tasks even in peacetime. These roads lead to daily used pump stations and buildings with greater importance and also to the central flood protection storage facilities.

Concrete pavement was typically used in the past, at present we do not build such roads in our directorate. However, the concrete roads leading mainly to agricultural facilities are explicitly suitable for the transportation of protection materials, thanks to their high weight tolerance.

Recently, in urban areas, paving-blocks are commonly used, as they fit more into urban environment and can be used as pedestrian promenades. On these sections it is also important to provide the conditions needed for protection material supply, so the weight tolerance should be carefully calculated when designing the substructure.

Of course the use of all kind of roads can be considered at the event of flood protection, regardless of its type or ownership; with sufficient traffic control, even exclusive use can be granted for the vehicles participating in the protection works.

\section{Damages made in the roads during protection works}

The extent of the damage caused in the roads during flood protection activity depends on the weather conditions, the volume of protection material needed and the total weight of the vehicles used.

Below I will demonstrate the possible damages of certain road types through photos taken in the territory of KÖTIVIZIG.

Figure 7 shows the damage of an unpaved road, where the deep rutting caused by heavyweight trucks is clearly visible. This happens typically in rainy weather and sodden ground. Reconstruction is cost effective, as only earth-moving machinery is needed, the material need is negligible. It is important to know though, that if rutting occurs on the dike crown, the 
reconstruction should be done in accordance with the regulations specifying the solidness of dike constructions. So it is better to avoid using dike crowns for transportation in rainy weather.
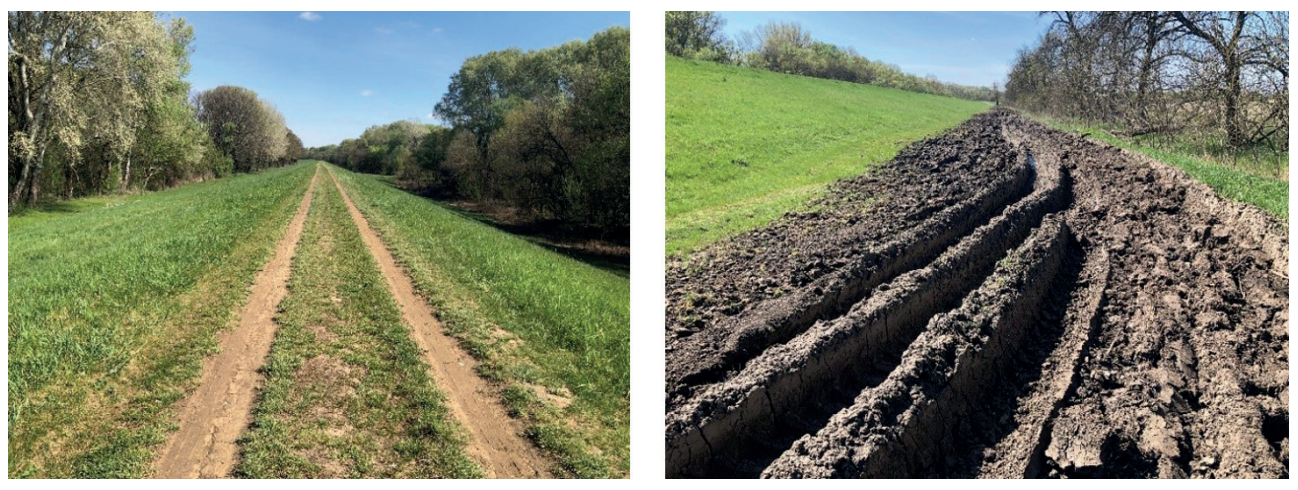

Figure 7. Well maintained and damaged unpaved road (periphery of Szolnok and Pély).

Source: photos by the author (15. 04. 2020.)

In Figure 8 a damaged tarmac road can be seen, where heavy-weight transportation caused lengthwise and web-like cracking on the surface.
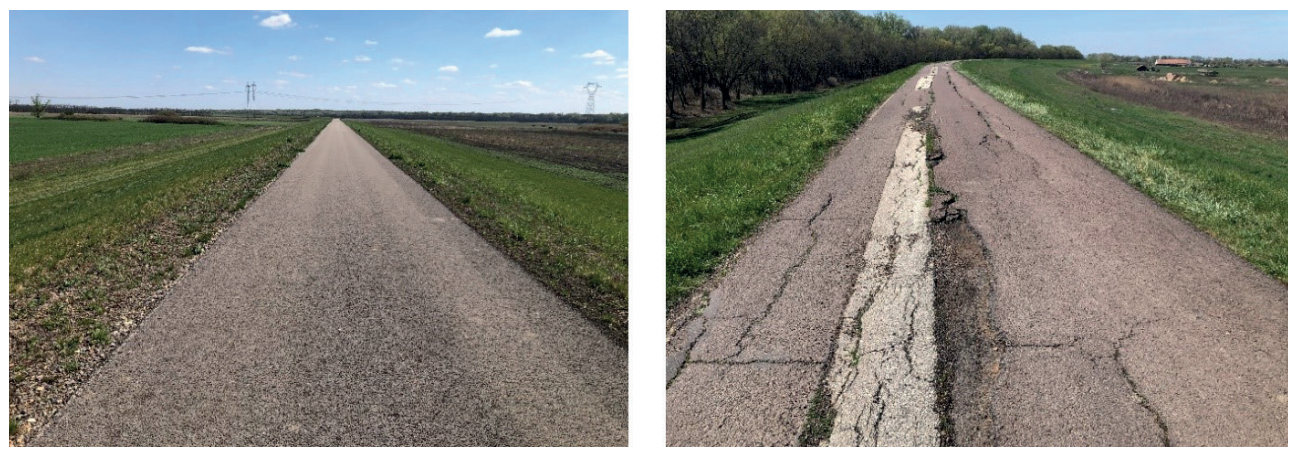

Figure 8. A tarmac road in good and damaged condition (periphery of Besenyszög and Pély)

Source: photos by the author (15. 04. 2020.)

The stripe with lighter color is the reconstructed part of the tarmac surface, made after the last flood protection. The reconstruction of tarmac roads has high costs relating both to material and labor.

On Figure 9 there is a damaged concrete road, where the surface broke and collapsed as a result of heavy traffic. We can see in the background that besides flood protection works there is also logging activity related transportation on this road, which also contributed to the damage. Before starting any flood protection works it is advised to make a survey of the general road conditions, to make the identification of damages possible at the reconstruction 
directly relating to flood protection. The reconstruction of concrete roads has similarly high material and labour costs as that of tarmac roads, since typically the renovation of the entire surface is needed.
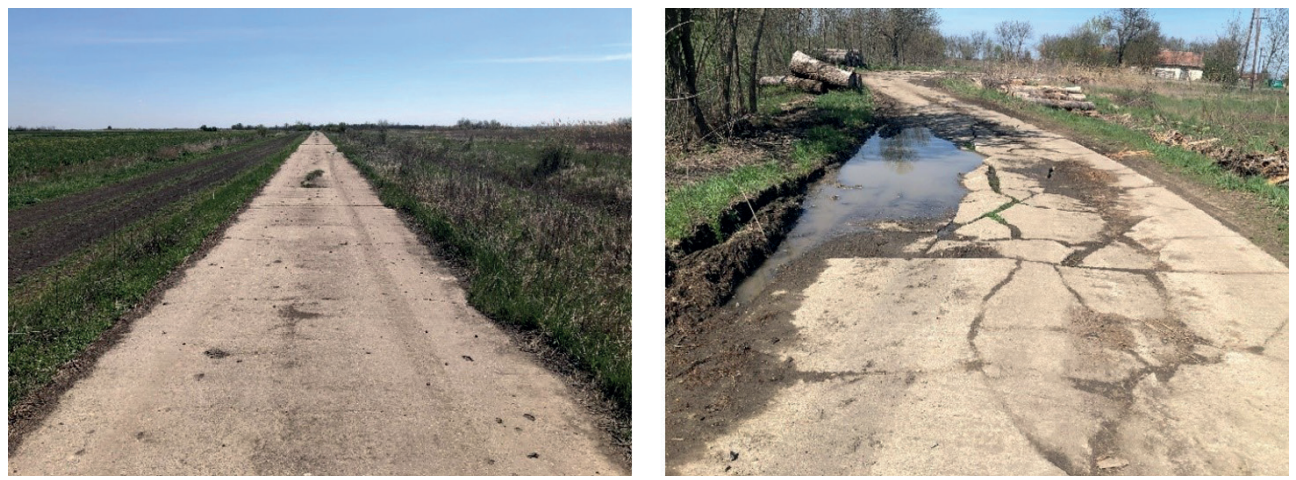

Figure 9. A concrete road in good and damaged condition (periphery of Besenyszög).

Source: photos by the author (15. 04. 2020.)

Figure 10 shows an approach route in urban environment, paved with concrete paving-blocks, at a location normally used as a promenade. The surface is cracked and sunk. If possible, the use of promenades for flood protection works should be avoided as there is a high risk of significant damages, the reconstruction of which is a very sensitive issue, it should be done as soon as possible due to the urban environment and the pressure from the civilians.
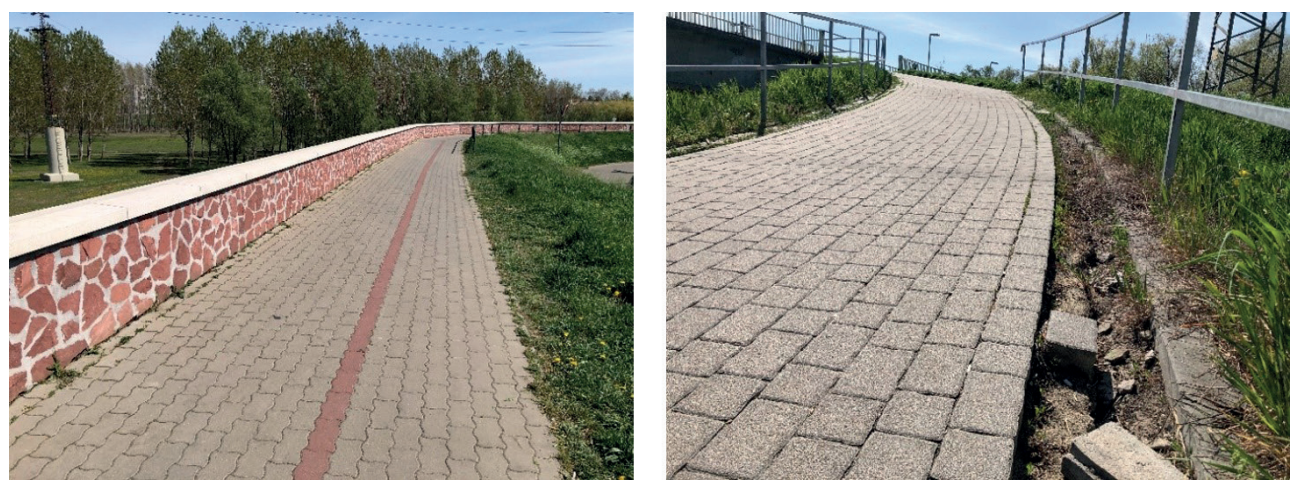

Figure 10. Paving-block surface in good and damaged condition (in Szolnok).

Source: photos by the author (15. 04. 2020.)

On Figure 11 we can see the damages made in a gravel road, where the heavy traffic caused potholes and sunk surface. It can be reconstructed in sections or even by spots, as the existing gravel can be easily refilled and the potholes can be repaired without significant machinery (for instance, there is no need for tarmac spreading or concrete slicking machine). 

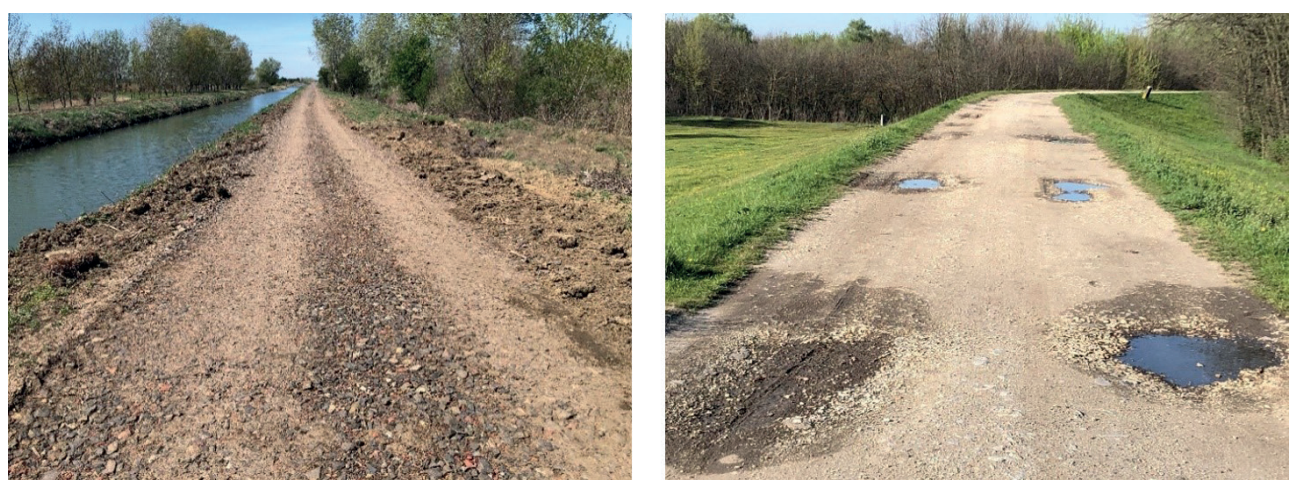

Figure 11. Gravel road in good condition and with damaged surface (periphery of Tiszasüly and Szolnok).

Source: photos by the author (15. 04. 2020.)

In general we can say that significant damages can be caused regardless of the type of the road surface, but the material costs of reconstruction are noticeably higher in case of solid surface roads. In the next chapter, I determine the specific costs of these reconstruction works.

\section{Reconstruction works following protective interventions}

I have made a cost analysis for the reconstruction of damages caused by flood protection related heavy traffic on different surface approach routes, based on the historical costs of reconstruction works made in the past years and the cost estimate manual ${ }^{11}$ published by the Construction Information Center in 2019. The results of the cost analysis referring to the net specific square meter costs of road surface reconstruction are summarised in Table 1.

After comparing the specific costs it is easy to see and calculate that the reconstruction of approach routes entails very significant costs in the budget of each flood protection. Considering the roads of three meter width the average reconstruction cost for unpaved roads is 1-3 million HUF/km, while it is 75-110 million HUF/ km in case of a concrete road. The costs of the intervention works at extreme level floods can reach up to billion magnitude, in which the proportion of costs covering the reconstruction of approach routes is very high. Unfortunately we can state that the reconstructions needed following flood protection works are not always completed entirely, mainly due to limited financial resources.

11 Miklós Palugyay-Masát and Kálmán Petro, Építőipari költségbecslésisegédlet [Construction cost estimate manual] (Budapest: Építésügyi Tájékoztatási Központ, 2019). 
Table 1. Reconstruction costs of different paving types

\begin{tabular}{|c|c|c|c|}
\hline Type of approach road & Type of work & $\begin{array}{c}\text { Net specific cost } \\
{\left[\mathrm{HUF} / \mathrm{m}^{2}\right]}\end{array}$ & $\begin{array}{c}\text { Net specific cost } \\
\text { [HUF/fm] (3 m width) }\end{array}$ \\
\hline $\begin{array}{c}\text { Agricultural area } \\
\text { (temporary) }\end{array}$ & Landscaping, deep loosening, finishing off & 300 & 900 \\
\hline Dirt road & Earth refilling, landscaping, profiling & 1,100 & 3,300 \\
\hline Gravel-stabilised road & Landscaping, compression, gravel filling, splay & 2,700 & 8,100 \\
\hline \multirow[t]{3}{*}{$\begin{array}{l}\text { Road of concrete } \\
\text { paving-blocks }\end{array}$} & $\begin{array}{c}\text { Pavement reconstruction (paving-blocks removal, } \\
\text { substructure reconstruction, } 3 \mathrm{~cm} \text { ballast layer, } \\
\text { repaving of paving-blocks) }\end{array}$ & 16,000 & 48,000 \\
\hline & $\begin{array}{c}\text { Pavement construction I ( } 15 \mathrm{~cm} \text { antifreeze layer, } \\
\text { 10-15 cm base layer, } 3 \mathrm{~cm} \text { ballast layer, } 8 \mathrm{~cm} \text { thick } \\
\text { paving-block layer) }\end{array}$ & 19,000 & 57,000 \\
\hline & $\begin{array}{c}\text { Pavement construction II (20 cm antifreeze layer, } \\
20 \mathrm{~cm} \text { base layer, } 3 \mathrm{~cm} \text { ballast layer, } 8 \mathrm{~cm} \text { thick } \\
\text { paving-block layer) }\end{array}$ & 24,000 & 72,000 \\
\hline \multirow[t]{4}{*}{ Tarmac road } & $\begin{array}{l}\text { Tarmac surface reconstruction I ( } 4 \mathrm{~cm} \text { milling, } \\
5 \mathrm{~cm} \text { wearing course) }\end{array}$ & 7,000 & 21,000 \\
\hline & $\begin{array}{l}\text { Tarmac surface reconstruction II ( } 8 \mathrm{~cm} \text { milling, } \\
7 \mathrm{~cm} \text { binder course and } 5 \mathrm{~cm} \text { wearing course) }\end{array}$ & 13,500 & 40,500 \\
\hline & $\begin{array}{c}\text { Constructing new tarmac surface I ( } 20 \mathrm{~cm} \text { anti- } \\
\text { freeze layer, } 20 \mathrm{~cm} \text { base layer, } 6 \mathrm{~cm} \text { binder course, } \\
4 \mathrm{~cm} \text { wearing course) }\end{array}$ & 23,000 & 69,000 \\
\hline & $\begin{array}{c}\text { Constructing new tarmac surface II (20 cm } \\
\text { anti-freeze layer, } 20 \mathrm{~cm} \text { subbase layer, } 9 \mathrm{~cm} \text { base } \\
\text { layer, } 7 \mathrm{~cm} \text { binder course, } 5 \mathrm{~cm} \text { wearing course) }\end{array}$ & 33,000 & 99,000 \\
\hline \multirow[t]{2}{*}{ Concrete road } & Reconstruction of concrete road & 25,000 & 75,000 \\
\hline & Constructing new concrete road & 37,000 & 111,000 \\
\hline
\end{tabular}

Source: edited by the author based on Palugyay-Masát and Petro, 'Építőipari'

\section{Conclusions}

We can state that in the territory of KÖTIVIZIG all kinds of road types and ownerships can be potentially taken into account at the event of flood protection. Occasionally even the exclusive use of certain roads is possible, with proper traffic control provided by the police, as it is already part of the directorate's flood protection routine. The possible routes needed for protection works should be mapped and registered in the future, referring to each flood wave level.

It is also visible that the approach routes used for transportation during flood protection works may suffer serious damages, the reconstruction of which requires several hundred million, or occasionally billion Forints.

By using the specific costs defined in this study the reconstruction costs resulting from the transportation of the materials needed for the intervention works of certain flood wave levels can be planned and calculated easily in the preparation plans.

Before starting any kind of flood protection work it is highly advised to make a status survey, to avoid financing the reconstruction works of damages originating from other than flood protection related transportation. 
The damages caused by transportation should be reconstructed following the flood wave, right after the temporary flood protection structures are removed. If this fails, the condition of the transportation roads will significantly decline, this way decreasing the efficiency of flood protection.

By preparing this study my goal was to use technical arguments to draw attention to the importance of the damage and reconstruction of transportation roads during the preparation for flood protection works along primary protection lines. The organising of transportation of protection material should be done in a methodical and scheduled way, taking the financial resources into consideration, this way preventing a disaster to happen.

\section{References}

Kovács, Sándor - Lovas, Attila - Gombás, Károly: 'Magyarország árvízvédelme az integrált vízgazdálkodásban a Tisza folyó példáján' [Flood protection of Hungary in integrated water management demonstrated on the example of River Tisza]. Hidrológiai Közlöny, no 4 (2016), 6-19.

KÖTIVIZIG alapító okirat [Deed of Foundation]. Budapest, 2019.

Nagy, László: Árvízvédekezés a településeken [Urban flood protection]. Budapest, Környezetvédelmi és Vízügyi Minisztérium, 2009.

Palugyay-Masát, Miklós - Petro, Kálmán: Épitöipari költségbecslési segédlet [Construction cost estimate manual]. Budapest, Építésügyi Tájékoztatási Központ, 2019.

Tóth, Rudolf - Hornyacsek, Júlia: 'Gondolatok a katasztrófa-elhárítás logisztikai kérdéseiről' [Thoughts about the logistics of disaster prevention]. Polgári Védelemi Szemle különkiadás (2008), 88-99.

\section{Legal References}

10/1997. (VII. 17.) KHVM rendelet az árvíz- és a belvízvédekezésröl [KHVM regulation about flood and excess water protection]. Available: https://net.jogtar.hu/jogszabaly?docid=99700010.khv (19. 04. 2020.)

1995. évi LVII. törvény a vízgazdálkodásról [Act on Water Management]. Available: https://net.jogtar. hu/jogszabaly?docid=99500057.tv (19. 04. 2020.)

232/1996. (XII. 26.) Korm. rendelet a vizek kártételei elleni védekezés szabályairól [Gov. regulation about the rules of protection works against water damages]. Available: https://net.jogtar.hu/ jogszabaly? docid=99600232. kor (19. 04. 2020.)

7/2012. (II. 10.) BM Utasítás a vízkárelhárítás országos irányításának szervezeti és müködési szabályzatáról [BM instruction on the rules of organisation and operation relating to protection works against water damages]. Available: http://njt.hu/cgi_bin/njt_doc.cgi?docid=143887 (19. 04. 2020.) 